\title{
Apparatus for illustrating the fall of bodies in a vacuum
}

\section{J. Puluj}

To cite this article: J. Puluj (1888) Apparatus for illustrating the fall of bodies in a vacuum, Philosophical Magazine Series 5, 25:152, 77-77, DOI: 10.1080/14786448808628152

To link to this article: http://dx.doi.org/10.1080/14786448808628152

曲 Published online: 29 Apr 2009.

Submit your article to this journal ๘

Џll Article views: 2

Q View related articles $\sqsubset$ 
An instrument in actual use having an opening of 8 millim. deflects its galvanometer 30 divisions of its scale when the hand is held a foot from the opening. A lighted match at six feet drives the needle around to its top.-Silliman's American Journal, December 1887.

\section{APPARATUS FOR ILLUSTRATING THE FALL OF BODIES IN A VACUUM. BY J. PULUJ.}

This apparatus has the advantage over others that it demonstrates the property that all bodies fall at the same rate in vacuo in a very simple manner and always with certainty. It consists of a glass tube 4 centim. wide, and 150 centim. in length, closed at both ends, having been previously exhausted; in it are contained the bodies, an iron bullet 1.5 centim. in diameter, and a light feather, in the quill-end of which is a fine iron needle-point 2 millim. in length. At the bottom of the vertical tube a caoutchouc stopper is inserted to protect the glass tube from breakage by the falling bullet; and at the top a brass flanged tubulure is cemented, in which an electromagnet with an iron core can be screwed. The tube is suspended vertically in the fork of a wooden support, by means of two pegs affixed to the electromagnet. For exciting the electromagnet a powerful battery of about 3 Bunsen's elements, or an accumulator consisting of three coils, is used.

To make the experiment, the tube is gently inclined until the feather and the ball are in the field of the electromagnet, the electrical current is closed, and the tube placed on the support. Both the feather and the ball are held at the top of the glass tube, and fall simultaneously the moment the current is opened.Berichte der Kaisertich. Alead. in Wien, Nov. 3, 1887.

ATTEMPT TO APPLY THE DIFFUSION OF GASES AND VAPOURS THROUGH POROUS BODIES TO DETERMINING THE AMOUNT OF MOISTURE AND CARBONIC ACLD IN THE SURROUNDING AIR. BY F. SCHIDLOWSKY.

The author has repeated the experiments of Dufour on the diffusion of air and aqueous vapour, and has come to the conclusion that in this phenomenon the absorption of vapour by porous bodies plays an important part.

If, for instance, we take a closed porous cylinder which contains dry air under ordinary atmospheric pressure, and in connexion with a water-manometer, and we place it in another cylinder in which the air is always saturated with aqueous vapour by the presence of water, then, according to Dufour, the manometer at once shows a decrease of pressure of about 10 to 12 millim., which afterwards becomes equalized.

Conversely, when the same cylinder is filled with moist air, and brought inside a dry cylinder, there is an increase of about 20 millim., which also is afterwards equalized.

These phenomena are thus explained by the author :- 